\title{
Pierre Mendès France, French Security Politics, and the European Defense Community
}

\author{
Emmanuel Konde \\ Albany State University, Albany, USA \\ Email: emmanuel.konde@asurams.edu
}

Received September $19^{\text {th }}, 2012$; revised October $25^{\text {th }}, 2012$; accepted November $8^{\text {th }}, 2012$

\begin{abstract}
This paper examines the role of Pierre Mendès France in the decision of the French National Assembly to reject the European Defense Community (EDC) proposed by René Pleven in October 1950 and signed by the [Antoine] Pinay government in 1952. Since the signing of the EDC treaty in 1952, successive governments of the Fourth Republic delayed action on ratification of the treaty until 1954 when Mendès France assumed the office of prime minister and, acting against conventional wisdom, forced the National Assembly to vote on it. The EDC was a collective attempt by western European powers, with the full support of the United States, to counterbalance the overwhelming conventional military ascendancy of the Soviet Union in Europe by forming a supranational European army. This collective security plan had its origins in the French government of René Pleven in 1950. Why the French signed the treaty establishing the EDC two years later in 1952, and then rejected it in 1954 after four years of debate, is of central concern to this paper, which explores the intersection and interplay of various factors that contributed to the negative French vote.
\end{abstract}

Keywords: Mendès France; Fourth Republic; Schuman Plan; EDC; France; Europe; Germany; United States

\section{Introduction}

At the cessation of World War II hostilities in 1945, Germany was occupied by the four major powers: the United States, Britain, France, and the Soviet Union. The great power competition for European zones of influence caused the United States to be very concerned about the stability of Europe. This concern prompted the United States to initiate the Marshall Plan as a first step toward ensuring European stability. Inaugurated in 1947, the Plan envisioned the economic recovery of Western Europe. Britain and France, sometimes reluctantly, followed the American lead for the inclusion of Germany in the recovery program. In general, however, the western occupying powers were in agreement that restrictions imposed after the cessation of hostilities should be eased gradually. But, whereas France entertained apprehensions about Germany's recovery, the United States tended to show primary concern for relieving the American taxpayer of the burden of supporting the Germans (Kennan, 1967: pp. 398 and 451). Uncertain about American commitment to permanent disarmament of Germany, France took the lead in initiating collective security proposals: the Schuman Plan and the EDC. This essay is concerned about the EDC, with particular emphasis on how Pierre Mendès France compelled the National Assembly to decide on it.

\section{The Great Powers and the German Problem}

The great power competition in post-war Europe, which reached its peak during the Berlin Crisis of 1948-1949, ultimately led to the creation of two German republics: a Federal Republic of Germany (FRG) in the Western Occupied Zones and a German Democratic Republic (GDR) in the Eastern Zone occupied by the Soviet Union. The new state of West Germany (FRG), although administered by a federal government and a parliament in Bonn, lacked the status of a sovereign state as ultimate sovereignty was vested in the Allied High Commission (McGeehan, 1971: pp. 12-13). In 1949 Germany’s economic recovery was not considered dangerous even by France because of the unanimous official agreement on continued demilitarization. All allied controls that were retained after the establishment of the Federal Republic were considered temporary, with the exception on security matters which, on the policy level, disarmament was to be permanent (Campbell, 1949: pp. 490491).

The three occupying powers of West Germany were agreed that there was a German problem and that the problem had to be managed somehow. As a point of fact, one of the important reasons for the United States sponsoring the North Atlantic Treaty Organization (NATO), and one of the French justifications for joining the organization, was the conviction that it would be beneficial in respect of managing the German problem. But it was on how this management of the German problem was to be achieved that both powers parted ways. For the United States, one of the most important functions of NATO included integration of Germany. This United States position was spelt in a report of the Senate Committee on Foreign Rela tions on the North Atlantic Treaty, which read:

While Germany is not a party to the North Atlantic Treaty the impact of the treaty upon Germany's future will be highly important. The committee believes it may make possible a solution of the German problem and a constructive integration of Germany into Western Europe (US Department of State, 1957: p. 850). 
France, on the other hand, held a point of view at variance with that of the United States. France would not have ratified the NATO treaty had the National Assembly not been assured that there was no possibility of Germany becoming a member of NATO. The French government had announced as early as 1949 that it would renounce its membership rather than accept Germany (Furniss, 1960: p. 38).

\section{French vs American Perception of Germany}

The fact that the United States and France perceived differently the role of a revived Germany in world affairs is understandable. Factors such as geographical location and historical experience, among others, influenced the attitudes and policy choices of both countries. France had Germany as neighbor to the northeast; the United States was far-removed from the continent, separated from Europe by the Atlantic Ocean. Twice in the twentieth century France had borne the brunt of Germany's military aggression. The same could not be said of the United States. The recent past was thus still too fresh in the French memory for her to even contemplate the idea of Germans bearing arms; not even in the context of the NATO framework. On the other hand, the growing military strength of the Soviet Union in Eastern Europe, and the memory of the harsh peace dictated to Germany after World War I loomed large in American thinking and veered the United States toward the integration of Germany in the Western alliance.

The Occupation Statute, also known as the Petersburg Agreement, signed by Konrad Adenauer and the three High Commissioners at the Petersburg Hotel in Bonn on November 22, 1949 contained reciprocal agreements by which Germany pledged "to maintain the demilitarization of the Federal territory and to endeavor by all means in its power to prevent the re-creation of armed forces of any kind” (Onslow, 1951: p. 450). Behind this façade of formal agreement the United States and Britain tended towards the return of Germany to an equal status other than military affairs. In contrast, the French were opposed to German equality in any area. This French attitude towards Germany prompted Dean Acheson to observe that "France was in the grip of an inferior neurosis" (Acheson, 1961: p. 33). There was little doubt about the opposition of Britain and France to the rearmament of Germany; it was however rumored that the United States was inclined to accept the rearmament of Germany (Onslow, 1951: pp. 451-452).

The rise of the Soviet Union after 1945 presented the main potential threat to the security and stability of Europe. But the perception and magnitude of the threat differed in Europe and the United States. Whereas Washington perceived the Soviet Union as a major threat to European stability, such a perception had not taken hold of continental and especially French thinking. It was much easier for the United States to be wholeheartedly opposed to communism: she hardly had any Communists at home. In France 20 per cent of the voters were Communists; 30 per cent were professed Marxists. This reality of familiarity with communism made the French more tolerant, even as this thinking ran counter to the conventional assumption of the time that the numerical superiority of Communists in any country constituted a threat (Guerard, 1959: p. 496). The French sense of insecurity, which seemed to reflect their military inferiority vis-à-vis Germany, was rooted in historical and psychological reality, even if it appeared somewhat exaggerated in the conditions that prevailed in post-war Europe. Given this state of affairs, therefore, it was plausible that "in the absence of a more encompassing political framework, 'equality' for Germany would mean the end of superiority for France” (McGeehan, 1971: p. 14). Be that as it may, the French security concern vis-à-vis Germany propelled her toward devising security arrangements designed to address and redress it.

\section{The Schuman Plan}

The Schuman Plan of May 1950 was France's first attempt at devising a security plan. It was initiated in response to French security concerns, namely to prevent another invasion by Germany. The prospect of a potentially powerful Federal Republic of Germany participating in the international system without any specifically European controls was a source of trepidation for France. It was against this background that Robert Schuman, the French Foreign Minister, presented Jean Monnet's proposal to put all of France and Germany's steel and coal production in an organization under common authority which would also be open to other European countries (Gowland, 2006: p. 279). The Schuman Plan's ultimate goal was to bind up German steel and coal production to the rest of Europe, which would provide for setting up common foundations for economic development as a first step in the federation of Europe. This process, the French believed, would change the destinies of regions that had been devoted to manufacturing munitions of war (See Royal Institute for International Affairs, 1950: pp. 315-317). The Schuman Plan met two immediate needs of Europe and France in the post-war era: it answered the call of advocates for European unity to enable the continent play a major role in international affairs, and France's need for the integration of Germany within a larger European framework so as to offer a meaningful guarantee against renewed German aggression (Tint, 1972: p. 47).

France feared that the United States was getting soft on Germany and that American policy was not sufficiently constant, even though it had been fairly consistent until the outbreak of the Korean War (McGeehan, 1971: p. 15). The highest American officials had often repeated the American commitment to keep Germany disarmed. On April 6, Secretary of State Dean Acheson declared that "the United States has firm international commitments, both for German disarmament and against German rearmament, and there is no change in the position" (Onslow, 1951: p. 455). High Commissioner McCloy reiterated this on April 22 when he said that "our fixed policy has been to impose and maintain effective controls against the revival of a German war machine...” (Quoted in Department of State Bulletin, 1950: pp. 587-588). Schuman's proposal was ostensibly not so much an economic but political proposal. Robert Schuman had written to the West German Chancellor Konrad Adenauer that the proposal was designed "to eliminate all risk of war and substitute for a ruinous rivalry an association founded upon common interest," and "to join in a permanent work of peace two nations which for centuries have faced each other in bloody rivalry" (Adenauer, 1966: p. 257).

Named after the French Foreign Minister Robert Schuman, the Schuman Plan was the basis of the treaty signed on April 18, 1951 that established the European Coal and Steal Community (ECSC). But the brain behind the Plan was Jean Monet who, at the creation of the ECSC High Authority at Luxembourg in August 1952, became its president (Grosser, 1961: pp. 233234). Commenting on the birth of the Schuman Plan, François Fontaine wrote: "Europe is born of a meeting: one day, a man 
had an idea and he communicated it to a man who had power and the next day the man exercised his power by proposing the idea to the people of Europe” (Fontaine, 1956: p. 99). But the Schuman Plan never materialized as Schuman first envisioned it. The invasion of South Korea by the Communist North on June 25, 1950 shattered that vision and ushered in its place the question of German rearmament, barely five years after the close of the Second World War. Robert Schuman had hoped that the ECSC would prepare the way for the gradual extension of European integration, a program which took its initial impetus in 1948 from the European Movement's call for the political unification of Europe (Grosser, 1961: p. 231).

Robert Schuman acknowledged in 1950, that "We would have preferred to build up the economic and political foundation a little further first, before starting on the military structure. But we have no choice in the matter; our tasks have been imposed on us" (Willis, 1968: p. 130) by the Korean War. Such then was the state of international politics, with circumstances and events prevailing over the abilities of statesmen to control. In the latter part of 1950, impelled by the Korea War, the United States pressed the rearmament of western Germany upon Great Britain and France and secured in September of that year the reluctant consent of the British Foreign Minister Ernest Bevin and his French counterpart Robert Schuman, the adoption in principle of this policy (Calvocoressi, 1954: p. 105; Willis, 1968: pp. 133-134). The rearmament of Germany was particularly disagreeable to France, and American insistence on it almost caused the fall of Bidault's government, but for the fact that the French Council of Ministers managed to reach an agreement on a new set of proposals which constituted an alternative to the policy sponsored by Washington. On October 24, 1950, Prime Minister René Pleven announced the proposals to the National Assembly. These proposals came to be known as the Pleven Plan (Calvocoressi, 1954: p. 163), which proposed the establishment of the European Defense Community (EDC).

\section{France's Fourth Republic and the EDC}

In the aftermath of the Liberation of France, the solidarity that was created among the political parties of the Resistance occasioned a reconciliation of parties that had formerly been op- posed to each other. In the prevailing climate of the time, it was natural that the provisional government formed by General Charles de Gaulle should have been what Léon Blum characterized in 1938 as a government of "national unanimity" (Goguel, 1952: p. 6), which included both Moderates and Communists. De Gaulle adopted this formula when he formed his government in November 1945, after the election of the First Constituent Assembly. From that point on, however, "national unanimity" became no more than a fiction. No sooner had the wartime comrades consumed their victory and regrouped their forces than the political tendencies of each political party resurface and assume proportions of old. And so they began to squabble among themselves.

It soon became obvious that the ruling elite was divided over the form the new Republic would take. The Communist party that had won big in the elections of October 1945, 26.5 per cent of the votes, thus became the largest political party in France. A result of this Communist victory was apprehension among many Moderates who feared that the grip of the Communists and Socialists on the government and the Assembly would produce some revolutionary changes in the political system and economic structure. The majority of radicals shared this fears, but were also suspicious of General de Gaulle's tendencies to exercise personal power. The Communists had been opposed to de Gaulle since 1944. Although represented in the Assembly and the provisional government, they were biding their time, waiting for the right moment to assure themselves of influence in the Assembly and government, and then move to dislodge de Gaulle whose personal authority stood in their way. Indeed, only the Popular Republicans and the Socialists seemed to be genuinely in favor of the governmental formula that was created in 1944 (Goguel, 1952: pp. 6-7).

At this juncture in French history, France needed a leader who could play the role of mediator. But the temperament of Gen. de Gaulle made him unfit for that role. Instead of mediating among the quarrelsome political parties, de Gaulle constantly tried to impose his views, especially on the constitutional question. Debate on the Constitution of the Fourth Republic centered on which branch of government should exercise more power: the legislative or executive? Some members of the Assembly urged greater stability through a strong executive; others, notably the Communists, favored concentrating power in a unicameral legislature subject to grassroots control by voters. De Gaulle remained aloof from this controversy, even though it was obvious that he favored a strong presidency. When de Gaulle discovered that his preference would not be accepted, he abruptly resigned his post as provisional president, probably in the hope that a wave of public support would bring him back to power with a mandate to impose his constitutional ideas. De Gaulle had miscalculated, for the public, stunned and confused, failed to act. Three days later the representatives of the Mouvement Républicain Populaire (MRP) reached an agreement with the Socialist and Communist parties for a tripartite government to be presided over by the Socialist Felix Gouin, at the time president of the Constituent Assembly (Chapsal, 1966: p. 117; Goguel, 1952: pp. 6-7). Thus was born the Fourth Republic in 1946.

\section{Confusion and Instability}

Born of confusion and ideological disharmonies, these traits were to define the Fourth Republic throughout its duration from 1946 to 1958 . The republic was characterized by instability of governments, with one government replacing another in a matter of months. Two of the longest serving prime ministers, Henri Queuille from September 1948 to October 1949, and Guy Mollet from January 1956 to May 1957 (Chapsal, 1966: pp. 180 and 277), “are considered as veritable Methuselahs among premiers, because they managed to wobble and totter uneasily for a whole year” (Op. cit., Guerard, 1959: p. 449). The governmental instability that France suffered from 1946 to 1958 resulted from the defects of the constitution. Certainly, the constitution was not a good one, and a defective constitution would necessarily lead to bad functioning of the political system. But it does not necessarily follow that a good constitution would lead to the crafting of good policy if the events and the politicians are otherwise disposed (See Chapsal, 1966: p. 135).

It was in this charged atmosphere of gamesmanship and party politics at its worst that René Pleven proposed the Pleven Plan on October 24, 1950, for an integrated European army incorporating the armies of six nations, including Germany and Italy (Goormaghtigh, 1954: p. 97; Kanter, 1970: p. 203). The 
plan provided for the creation of a European army under a minister of defense who would be responsible to supranational political authorities. Under the plan, each country was to build up a force of its own at the outset, and Germany was to build up a force for its own defense on land. A European ministry was to be organized to work in close cooperation with defense ministers of other participating countries. Great Britain and the Scandinavian countries were expected to participate. René Pleven was careful to point out that those countries with overseas commitments would be entitled to reserve forces which would not be integrated. Germany would not have "contingents" but only small "units". The European minister would be assisted by a defense council, and both would have to report to an assembly which could be that of the Coal and Steel Community (Goormaghtigh, 1954: p. 97).

Although the plan for the creation of the EDC was supported in the French National Assembly by a vote of 348 to 224 (Willis, 1968: p. 132), the Assembly clearly stated that it remained opposed to the reconstitution of a German army and general staff by 402 to 168 votes (Goormaghtigh, 1954: p. 98). Two years later in May 1952, the government of Pinay signed the treaty creating the European Defense Community (See Kanter, 1970: p. 203; Chapsal, 1966: p. 244). Since then no other French government took the initiative to present the treaty to the National Assembly for ratification (Calvocoressi, 1954: p. 50). By late 1954 France, the originator of the concept that led to the establishment of EDC was the only participating country that had not ratified the treaty. At this juncture the EDC had become a somewhat risky affair, assuming what Chapsal referred to as the likeness of a "religious war" (Op. cit., Chapsal, 1966: p. 244). A succession of French Prime Ministers simply refused to ask the National Assembly to approve the instrument to which the French government has set its hand and seal (Calvocoressi, 1954: p. 50). It was thus left to Pierre Mendès France to dare what his predecessors could not do. It is said that Mendès France's immediate predecessor, Joseph Laniel who served as prime minister from June 28, 1953 to June 19, 1954, had admonished him not to bring the treaty before the Assembly because: "There is not a majority for this treaty. Do not try to obtain its ratification” (Quoted by Lacouture, 1984: p. 266). Mendès France listened to Laniel but he did not heed this admonition.

\section{The Politics of Mendès France}

Pierre Mendès France was a French statesman, lawyer, and economist. He rose to the premiership of France in 1954, and though his government lasted only seven months, Mendès France exerted energetic leadership that resulted in extricating France from Indochina and suggested to people that the Fourth Republic was impotent primarily because it lacked able and courageous statesmen. Born to Jewish parents in Paris on January 11, 1907, Mendès France was educated at the University of Paris, from where he graduated with a doctorate in law and became the youngest member of the Paris Bar Association in 1928. He joined the Radical Socialist Party, the traditional party of the French middle-class centre-left in 1924, and practiced law in Normandy and from 1932 to 1940 . Mendès France served in the National Assembly as a Radical party deputy from Eure. At the time the youngest member of that Assembly, Mendès France's abilities were instantly recognized. He was appointed Secretary of Finance in the 1936 Popular Front gov- ernment of Léon Blum. When the Second World War broke out, Mendès France joined the air force. He was arrested by the Vichy government after France capitulated to Nazi Germany on trumped up charges of desertion and sentenced to six years in prison. On June 21, 1941, he escaped and made his way to Britain, and fought in the Free French forces of General Charles de Gaulle.

From Britain, de Gaulle dispatched Mendès France to his Finance Commission in Algeria, and then appointed him as head of the French delegation to the 1944 monetary conference at Bretton Woods. When de Gaulle returned to liberated Paris in September 1944, he appointed Mendès France as Minister for National Economy in the provisional government. But Mendès France and Finance Minister René Pleven fell-out over inflation control policy: Mendès France advocated state intervention through regulation of wages and prices to control inflation, while Pleven favored free market policies. When de Gaulle sided with Pleven, Mendès France resigned. Nonetheless, because de Gaulle still valued his abilities, he appointed Mendès France as a director of the International Bank for Reconstruction and Development, and as the representative of France in the United Nations Economic and Social Council.

In the elections of 1946 Mendès France won a seat in the National Assembly. By 1950 he had emerged as the most effective critic of the succession of ineffective governments that were unable or unwilling to end the war in Indochina. Mendès France insisted that the war drained France of energy and resources needed to modernize and invigorate the economy. Consequently, on Sunday, June 13, 1954, he was summoned to the Elysée by President René Coty. Mendès France was not surprised; he could not have been surprised. No other French politician had contributed more than he to the fall of the LanielBidault government, and it is good democratic practice to select an alternative government, as Coty did, by recourse to an alternative approach to democratic political practice offered by Mendès France (Lacouture, 1984: p. 211).

\section{A Resolute Statesman}

The chief concern of the Fourth Republic was the war in Indochina. Mendès France had declared to the country that George Bidault had not done everything to put an end to the fighting, and that on the contrary Bidault had risked escalating the war. On the floor of the National Assembly, Bidault had challenged Mendès France to do better. In this extraordinary struggle of men and policies, there seemed no other fitting solution than for the head of state to call on the man who offered a different course of action. Designated Prime Ministerelect by President René Coty on June 13, Mendès France was elected premier on June 18, 1954 by one of the strongest and most complex majorities in the history of the Fourth Republic. Members of the national Assembly supported him by 471 votes to 14 . Since de Gaulle, no other Frenchman had so mobilized public feeling in his favor. Perhaps more admired than loved, Mendès France was followed by a vast current of opinion which expected from him initiatives, drive, and impetus (See Lacouture, 1984: pp. 211, 214 and 265). The personality of Mendès France evoked certain disquietudes in different quarters. His past in the Popular Front and sympathies for Communists made Americans extremely concerned "Until the day John Foster Dulles first met with Mendès France and called him a “superman” (Op. cit., Chapsal, 1966: p. 238). 
In his investiture speech of June 16, 1954, Mendes France outlined the priorities of his government as follows: First, the termination of the war in Indochina in 30 days, or else he would resign; second, the revitalization of the French economy, and; third, not to delay a decision any longer on the EDC. Strongly believing that it was the responsibility of his government to bring the question of ratification of the EDC to the Assembly and have it decided upon, he told the National Assembly on June 16 that his government would be one of national renovation and would set things right (Mendès France, 1955: p. 16). Pursuant to this pledge in forming his cabinet, he conspicuously departed from the old practice of consultation with the political parties (Chapsal, 1966: p. 239). As a result, his choice of cabinet members did not take place as freely as he would have liked. The Socialist party, which contained the bulk of his supporters, refused to participate because of Mendès France's insistence on not adhering to the usual procedure of designation by the group, and because party division over the EDC posed a risk of break-up in the event it were submitted to the test of power (Lacouture, 1984: p. 215). French opinion about the EDC was divided. Raymond Aron wrote that:

From January 1953 to August 1954 took place the greatest ideological debate France has known since the Dreyfus affair; its most visible stake was German rearmament, but its ultimate significance concerned the very existence of the French national state. Any attempt to sum up the debate must seem contentious, since each party mingled the pros and cons of the logically consistent (Aron, 1957: p. 10).

As the debate raged on, it became obvious that the feeling against the EDC, both in the National Assembly and among the public, grew stronger. Those who believed that cooperation between France and Germany was essential for security and progress of Western Europe continued to support it, but others remained implacably hostile to the EDC (Calvocoressi, 1954: p. 137).

\section{Negotiating the European Defense Community}

The position that Mendès France took was somewhat ambiguous. His commitment to the EDC was apparently derived from the fact that it was the French government that had proposed it; and from his fear that the United States and Germany might present France with a fait accompli-a military arrangement between Washington and Bonn, about which France would not have been able to do anything. It was against this fearful prospect that Mendès France struggled but definitely did not like the idea (Lacouture, 1984: p. 260). From the very start Mendès France considered the EDC unacceptable in its original form. So he formed his government with an eye on the EDC, in such a way that half the cabinet consisted of pro-EDC members and the other half anti-EDC (Werth, 1957: p. 126). He charged two of his ministers, Bourges-Maunoury (pro) and General Koenig (anti) to work on a rapprochement between the opposing positions (Chapsal, 1966: pp. 244-245). He then proposed a compromise that he thought would be acceptable to the allies and most Frenchmen, and this was the object of Mendès France's meeting with the other signatories of the EDC treaty in Brussels from August 19 to 22. From this meeting came the Brussels protocols which, "by discriminating against Germany, by allowing members to withdraw from EDC if Germany ever became united, and by associating Britain closely with the EDC, and generally weakening the supranational nature of the agreement, (Mendès France) infuriated the EDC 'purists', not only in Belgium and Holland and Germany, but also in France” (Op. cit., Werth: 1957, p. 126).

While Mendès France was in Brussels negotiating a compromise on the EDC, the pro-EDC elements in France, notably Robert Schuman and Andre Philip, wrote articles in the Figaro and France-Tireur, respectively, in which they castigated the Brussels protocols saying that there was a majority in the Assembly for the EDC, and claimed that if the treaty was not ratified, it was the fault of the President of the Council (See Chapsal, 1966: p. 246)—Mendès France. The EDC “purists” were determined to stop at nothing in their endeavor to discourage Mendès France's counterparts at Brussels from making any concessions to him. Schuman even directly communicated with West Germany's Chancellor Adenauer, telling him that the EDC would be passed by the French National Assembly if only the EDC ministers meeting in Brussels prove adamant in their attitude toward Mendès France. At the same time, pressure outside of France also came to play heavily on the deliberations at Brussels.

The opening of the Brussels conference coincided with a telegram from Winston Churchill, in which the Briton clearly indicated that whatever happened in Brussels Germany would be rearmed. Aggravating things even more was the presence of the United States Ambassador to the European Community, David Bruce, who encouraged the Belgian Foreign Minister Paul-Henri Spaak to be uncompromising. This direct British and United States intervention caused the greatest annoyance to Mendès France. Ten days after the break down of negotiations at the Brussels Conference, and Mendès France's last minute abortive attempt to have Britain join the EDC; the National Assembly defeated the EDC by 319 to 264 votes (Werth, 1957: pp. 126-127). In the aftermath of the failed Brussels Conference, and a few days before the National Assembly voted on the EDC proposal, Mendès France had spoken to the French people on August 24 in these words:

Since returning to Paris, I wanted to re-establish contact with you, and to tell you that, throughout the difficult period, I had not ceased for a moment to think of you, that is, of the country in whose name I was speaking. That was why, after making all reasonable concessions, I decided that I could not accept the proposals that would have shocked the conscience of so many Frenchmen, and which were likely to be disavowed by their deputies (Quoted in Werth, 1957: p. 128).

A man of conviction and of action, Mendès France had decided that his government would not vote, one way or the other, on the EDC. He was not going to have the EDC ratified in the form which he had himself condemned before going to Brussels. It is probable that Mendès France acted from the stand point of French national interest. If so, then the grand old man Édouard Herriot, former President of the National Assembly, must to have said it all when he declared in a voice that seemed to boom from the depths of French history: "a country that was not master of its army was not master of its destiny" (Werth, 1957: p. 127).

\section{Why France Rejected the EDC}

Why the French rejected the EDC, even though it originated 
in France, has elicited some opinions that attempt to explain the decision. Some of these have tended to blame the rejection on the "inconsistent and chaotic politics of France's Fourth Republic", with special reference to the behavior of the deputies in the National Assembly. This view maintains that because the members of the Assembly were ideologically committed and motivated by personal concerns and individual ambition, the result was that considerations of political advancement formed the basis for their voting performance (Kanter, 1970). This is an important argument, but one that does not consider the historical experience of France and Frenchmen, and which leaves out the fact that it was Frenchmen, elected by other Frenchmen in a democratic nation, who voted on the destiny of France by rejecting the EDC. Perhaps the National Assembly vote was a bad choice in the eyes of the outside world; but it was nevertheless the choice of France.

Others have sought to explain the French action by reference to the delay in presenting the EDC proposal to the National Assembly for ratification, and change in the composition of that body from political parties which favored the EDC to parties that opposed it. This trend showed an absolute and relative decline of the political parties and individual statesmen most favorable to the European idea. By 1954, at the time of the vote, this perspective contends, the parties and statesmen most favorably disposed to the EDC and responsible for initiating it were either in the opposition or out of the government (Fauvet, 1957). While this explanation reflects the evolution of political parties and the attitudes of individual politicians who were supportive of the EDC proposal in government and the National Assembly, one is hard pressed to understand why in 1952, immediately after the treaty was signed, the Pinay government failed to seek its ratification. Again, was any French statesman, from the inception of the EDC idea by René Pleven in 1950, to its ultimate defeat during the Mendès-France government in 1954, actually favorably disposed to the EDC to stake out his reputation for it? If so, why did a man of stature like Robert Schuman, for example, not struggle to have it ratified in 1952 and 1953? It is true that the constellation of political parties and representatives in the National Assembly did change; and that the initiators of the EDC were no longer in government. But these changes do not quite explain why the treaty was defeated.

A plausible explanation can be derived France's concerns about the changed state of international relations in 1954. The threat of Soviet aggression, so obvious at the time when the EDC treaty was signed in 1952, had by 1954 diminished considerably. Hence there was no longer the same military need for a substantial contribution of German forces to the defense of Western Europe. This sense of security among the French was greatly enhanced after the death of Joseph Stalin in 1953 (Calvocoressi, 1954: pp. 137-138). Also influencing the French decision to reject the EDC was their ever-present fear of German aggression. The EDC entailed the formation of 12 divisions of German military forces because "European military integration was only realized on the army corps level, and for the Commissariat on the administrative level. Those who opposed the rearmament of Germany had good reason to denounce, behind the EDC camouflage, the revival of the Wehrmacht" (Aron, 1957: p. 11).

The French decision to reject the EDC was deeply rooted in the consideration of their national interest. France spoke through her National Assembly, through the representatives of the peo- ple, and through the government represented by Pierre Mendès France. Within Europe, Britain provided the only security blanket that France desired. And though Britain was solemnly bound to France by a whole series of treaties, the English were bound but not fully committed. France wanted Britain not just as a friendly outsider but as a part and parcel of the European system of which Britain was the keystone (Guerard, 1959: p. 498). When Britain refused to take her proper place among the nations of Europe, France had no other choice but to say no to EDC.

\section{REFERENCES}

Acheson, D. (1961). Sketches from life of men I have known. New York: Harper \& Brothers.

Adenauer, K. (1966). Memoirs, 1945-1953. Chicago: Henry Regenry.

Aron, R. (1957). Historical sketches of the great debate. In D. Lerner, \& R. Aron (Eds.), France defeats EDC. New York: Frederick A. Praeger.

Calvocoressi, P. (Ed.) (1954). Survey of international affairs, 1951. London: Oxford University Press.

Campbell, J. C. (1949). The United States in world affairs 1948-1949. New York: Harper \& Brothers.

Chapsal, J. (1966). La vie politiques en France depuis 1940. Paris: Presses Universitaires de France.

European Union (1920). The Schuman declaration—9 May 1920. URL (last checked 28 August 2012).

http:\leuropa.edu/basic-information/symbols/europa

Fauvet, J. (1957) Birth and death of a treaty. In D. Lerner, \& R. Aron (Eds.), France defeats the EDC (pp. 128-164). New York: Frederick A. Praeger.

Fontaine, F. (1956). La nationfrein. Paris: Julliard.

France, P. M. (1955). Sept mois et dix sept jours. Paris: Rene Julliard.

Furniss, E. S. (1960). France, troubled ally: De Gaulle's heritage and prospects. New York: Frederick A. Praeger.

Goguel, F. (1952). France under the Fourth Republic. Ithaca, NY: Cornell University Press.

Goormaghtigh, J. (1954). France and the European defense community. International Journal, 9, 96-106. doi:10.2307/40197989

Gowland, D. et al. (Eds.) (2006). The European Mosaic. London: Longman.

Grosser, A. (1961). La IVe République et sa politique extérieure. Paris: Armand Colin.

Guerard, A. (1959). France: A modern history. Ann Arbor: University of Michigan Press.

Kanter, A. (1970). The European Defense Community in the French National Assembly. Comparative Politics, 2, 203-228. doi:10.2307/421278

Kennan, G. F. (1967). Memoirs 1925-1950. Boston: Atlantic-Little Brown.

Lacouture, J. (1984). Pierre Mendes France. New York and London: Holmes and Meier.

McGeehan, R. (1971). The German rearmament question. Urbana: University of Illinois Press.

Onslow, C. G. D. (1951). West German rearmament. World Politics, 3, 450-485.

Royal Institute for International Affairs (1953). Documents on international affairs, 1949-1950. London: Oxford University Press.

Tint, H. (1972). French foreign policy since the second world war. London: Weidenfeld and Nicolson.

United States, Department of State (1957). American foreign policy, 1950-1955: Basic documents. Washington DC: Department of State.

United States (1950). Department of state bulletin.

Werth, A. (1957). The strange history of Pierre Mendes-France and the great conflict over North Africa. London: Barrie Books.

Willis, F. R. (1968). France, Germany and the New Europe 1945-1967. Oxford: Oxford University Press. 